\title{
PENGARUH pH TERHADAP AKTIVITAS ANTIOKSIDAN EKSTRAK DAUN MIANA (Coleus atropurpureus L. Benth)
}

\author{
Fitri Eka Giuliana ${ }^{1, *}$, Mirhansyah Ardana1, Rolan Rusli ${ }^{1,2, \dagger}$ \\ ${ }^{1}$ Laboratorium Penelitian dan Pengembangan Kefarmasian "Farmaka Tropis", \\ Fakultas Farmasi, Universitas Mulawarman, Samarinda \\ *Email:giu.gmbel@gmail.com \\ ${ }^{2}$ Kelompok Bidang Ilmu Kimia Farmasi, Fakultas Farmasi, Universitas \\ Mulawarman, Samarinda \\ 'Email: rolan@farmasi.unmul.ac.id
}

\begin{abstract}
Ethanol extract of the leaves miana has good antioxidant activity with IC So value was 48.04 ppm. Stability of antioxidants can be affected by several factors such as oxygen, light, $\mathrm{pH}$, and temperature. Effect of $\mathrm{pH}$ on the antioxidant activity can be viewed by using citrate buffer $p H 3,4$ and 5.3 and citrate - Phosphate buffer $p H$ 3, 4, 5.3, 6, 7 and 8. Test of antioxidant activity with DPPH method (1,1-diphenyl2-picrylhydrazyl) using a UV-Vis spectrophotometer produce the most good IC 50 values at pH 4 with citrate buffer (IC 5029.97 ppm) and Citrate - Phosphate buffer (IC50 $30.88 \mathrm{ppm})$.
\end{abstract}

Key words: Coleus atropurpureus L. Benth., Antioxidant, DPPH, IC 50.

\begin{abstract}
ABSTRAK
Ekstrak etanol daun miana memiliki aktivitas antioksidan yang baik dengan nilai $\mathrm{IC}_{50}$ 48,04 ppm. Stabilitas dari antioksidan dapat dipengaruhi oleh beberapa faktor seperti oksigen, cahaya, $\mathrm{pH}$, dan suhu. Pengaruh $\mathrm{pH}$ terhadap aktivitas antioksidan dilihat dengan menggunakan buffer Sitrat $\mathrm{pH} \mathrm{3,4}$ dan 5,3 serta buffer Sitrat Fosfat pH 3; 4; 5,3; 6; 7; dan 8. Uji terhadap aktivitas antioksidan dengan metode DPPH (1,1-diphenyl-2-picrylhydrazyl) menggunakan spektrofotometer UV-Vis menghasilkan nilai $\mathrm{IC}_{50}$ yang paling baik pada $\mathrm{pH} 4$ dengan buffer Sitrat (IC 50 29,97 ppm) dan dengan buffer Sitrat - Fosfat (IC50 30,88 ppm).
\end{abstract}

Kata kunci: Coleus atropurpureus L. Benth., Antioksidan, DPPH, $\mathrm{IC}_{50}$. 


\section{PENDAHULUAN}

Kesehatan merupakan hal terpenting dan utama dalam kehidupan manusia. Perkembangan industri dan gaya hidup manusia menimbulkan berbagai dampak, baik dampak positif maupun negatif. Salah satu dampak negatif yang perlu diwaspadai adalah timbulnya berbagai penyakit degeneratif [1]. Penyakit degeneratif diakibatkan proses metabolisme tubuh yang menghasilkan radikal bebas berlebihan sehingga menyebabkan kerusakan pada fungsi sel-sel tubuh [2].

Radikal bebas adalah atom yang memiliki satu atau lebih elektron tidak berpasangan di kulit terluar sehingga sangat reaktif dan mampu bereaksi dengan lipid, protein, karbohidrat atau DNA. Senyawa radikal bebas meliputi hidroksil, anion superoksida, hidrogen peroksida, asam hipoklorat, oksigen singlet, dan peroksil [3]. Pengaruh negatif radikal bebas ini dapat dihambat oleh adanya antioksidan. Antioksidan merupakan senyawa yang dapat menghambat reaksi oksidasi, dengan mengikat radikal bebas dan molekul yang sangat reaktif. Antioksidan merupakan senyawa pemberi elektron (electron donor) atau reduktan. Senyawa ini memiliki berat molekul kecil, tetapi mampu menginaktivasi berkembangnya reaksi oksidasi, dengan mencegah terbentuknya radikal. Secara biologis, pengertian antioksidan adalah senyawa yang mampu menangkal atau meredam dampak negatif oksidan dalam tubuh. Antioksidan bekerja dengan cara mendonorkan satu elektronnya kepada senyawa yang bersifat oksidan sehingga aktivitas senyawa oksidan tersebut bisa dihambat [4].

Beberapa antioksidan dapat dihasilkan dari produk alami, seperti dari rempah-rempah, teh, coklat, dedaunan, biji-biji serelia, sayur-sayuran, enzim dan protein. Kebanyakan sumber antioksidan alami berasal dari tanaman dan umumnya merupakan senyawa fenolik yang tersebar di seluruh bagian tanaman baik di kayu, biji, daun, buah, akar, bunga maupun serbuk sari. Diketahui hampir 80 persen dari total antioksidan dalam buah dan sayuran berasal dari flavonoid, yang dapat berfungsi sebagai penangkap anion superoksida, lipid peroksida radikal, kuensing oksigen singlet, dan pengkelat logam [5]. Daun miana (Coleus atropurpureus L. Benth.) mengandung flavonoid dengan aktivitas antioksidan yang cukup tinggi dimana $\mathrm{IC}_{50}$ yang dimiliki pada ekstrak etanolnya yaitu 48,04 ppm [6]. Corak, bentuk, dan warna miana beranekaragam, tetapi yang berkhasiat obat adalah daun yang berwarna merah kecoklatan [7].

Stabilitas dari antioksidan dapat dipengaruhi oleh beberapa faktor seperti oksigen, cahaya, $\mathrm{pH}$, dan suhu. Suhu memiliki peranan dan pengaruh yang sangat penting terhadap kestabilan antosianin. Menurut Hendry dan Houghton (1996), suhu penyimpanan maupun suhu proses pengolahan mempengaruhi degradasi antosianin [8]. Jadi, pada suhu pengolahan yang tinggi dan selama penyimpanan akan menyebabkan degradasi antosianin [9] begitu pun dengan pengaruh $\mathrm{pH}$ salah satu contohnya adalah senyawa antosianin delphinidin yang terkandung dalam bunga rosella yang dapat larut dalam asam dan tidak stabil dalam larutan netral atau basa [10]. Antosianin merupakan salah satu senyawa yang menghasilkan efek antioksidan dan juga merupakan komponen kimia yang terdapat pada tanaman miana [11]. Berdasarkan uraian di atas maka dilakukan uji pengaruh $\mathrm{pH}$ terhadap aktivitas antioksidan ekstrak daun miana. 


\section{METODE PENELITIAN}

\section{Bahan}

Bahan yang digunakan pada penelitian ini yaitu berupa daun miana, etanol 96\%, air suling, asam sitrat, natrium sitrat, $\mathrm{Na}_{2} \mathrm{HPO}_{4}$, dan DPPH.

\section{Peralatan}

Peralatan yang digunakan pada penelitian ini yaitu timbangan analitik, rotary evaporator, tabung reaksi bertutup, sonikator, kuvet kuarsa, mikropipet, vortex, $\mathrm{pH}$ meter, spektrofotometer UV Vis double beam (HALO DB-20S), labu ukur coklat, pipet ukur, pipet volume dan peralatan kaca lain yang umum yang digunakan di laboratorium.

\section{Prosedur}

\section{Pengumpulan Sampel}

Sampel merupakan daun miana yang diperoleh dari Kecamatan Samarinda Seberang Kelurahan Mangkupalas.

\section{Ekstraksi}

Simplisia daun miana (Coleus atropurpureusL. Benth.) dimasukkan ke dalam wadah maserasi. Kemudian dimaserasi dengan menggunakan pelarut etanol 96\%, dan didiamkan selama 3 hari. Maserat (hasil maserasi) dipekatkan dengan menggunakan rotary evaporator hingga didapatkan ekstrak kental etanol.

\section{Pengujian Aktivitas Antioksidan Ekstrak Daun Miana}

Aktivitas antioksidan ditentukan dari nilai $\mathrm{IC}_{50}$ yang dihitung dengan menggunakan metode DPPH dengan alat spektrofotometer UV Vis. Terlebih dahulu dibuat buffer Sitrat pH 3, 4, dan 5,3 dan buffer Sitrat - Fosfat pH 3; 4; 5,3; 6; 7 dan 8 sebagai pengatur suasana asam, netral dan basa pada ekstrak etanol daun miana. Ekstrak etanol daun miana dibuat 5 seri konsentrasi yaitu 10, 30, 50, 70, dan $90 \mathrm{ppm}$ dengan melarutkannya menggunakan etanol sebanyak $5 \%$ terlebih dahulu kemudian ditambah buffer sesuai $\mathrm{pH}$ masing-masing. Ke 5 seri konsentrasi dimasukkan ke dalam tabung reaksi bertutup dan ditambahkan DPPH (40 ppm) kemudian didiamkan selama 30 menit lalu ditentukan serapannya menggunakan spektofotometer UV-Vis pada panjang gelombang maksimum. Hasil serapan digunakan untuk menghitung persen peredaman radikal bebas kemudian dimasukkan ke dalam persamaan yang diperoleh dari kurva regresi linier sehingga didapatkan nilai $\mathrm{IC}_{50}$.

Perhitungan persen peredaman dengan menggunakan rumus [12]:

$$
\% \text { Peredaman }=\frac{\text { Abs.blanko - Abs.sampel }}{\text { Abs.blanko }} \times 100 \%
$$




\section{HASIL DAN PEMBAHASAN}

Hasil pengamatan serapan dan peredaman radikal bebas ekstrak etanol daun miana pada konsentrasi 10, 30, 50, 70 dan 90 ppm dengan buffer Sitrat disajikan dalam tabel 1 serta serapan dan peredaman radikal bebas ekstrak etanol daun miana pada konsentrasi 10, 30, 50, 70, dan 90 ppm dengan buffer Sitrat - Fosfat disajikan dalam tabel 2.

Hasil peredaman digunakan untuk menghitung aktivitas antioksidan $\left(\mathrm{IC}_{50}\right)$. Analisis nilai $\mathrm{IC}_{50}$ dihitung berdasarkan persamaan regresi linier yang didapatkan dengan memplot konsentrasi larutan uji dan persen peredaman DPPH sebagai parameter aktivitas antioksidan. Konsentrasi larutan uji sebagai absis dan persen peredaman sebagai ordinat [13]. Hasil persamaan regresi linier yang diperoleh untuk ekstrak etanol daun miana dengan buffer Sitrat disajikan dalam gambar 1 serta hasil persamaan regresi linier yang diperoleh untuk ekstrak etanol daun miana dengan buffer Sitrat- Fosfat disajikan dalam gambar 2.

Tabel 1.Nilai Serapan dan Peredaman Ekstrak Etanol daun Miana dengan Buffer Sitrat

\begin{tabular}{ccccccc}
\hline \multirow{2}{*}{$\mathbf{p H}$} & $\begin{array}{c}\text { Konsentrasi } \\
(\mathbf{p p m})\end{array}$ & $\mathbf{1}$ & $\mathbf{2}$ & $\mathbf{3}$ & Rata-rata & $\begin{array}{c}\text { Peredaman } \\
(\boldsymbol{\%})\end{array}$ \\
\hline 33 & DPPH & 0,653 & 0,653 & 0,653 & 0,653 & - \\
& 10 & 0,510 & 0,524 & 0,529 & 0,521 & 20,21 \\
& 30 & 0,293 & 0,278 & 0,281 & 0,284 & 56,51 \\
& 50 & 0,103 & 0,108 & 0,100 & 0,104 & 84,07 \\
& 70 & 0,061 & 0,084 & 0,068 & 0,071 & 89,13 \\
& 90 & 0,045 & 0,048 & 0,047 & 0,047 & 92,80 \\
\hline 4 & DPPH & 0,736 & 0,736 & 0,736 & 0,736 & - \\
& 10 & 0,595 & 0,601 & 0,609 & 0,602 & 18,21 \\
& 30 & 0,321 & 0,320 & 0,319 & 0,320 & 56,52 \\
& 50 & 0,116 & 0,110 & 0,112 & 0,113 & 84,65 \\
& 70 & 0,082 & 0,086 & 0,084 & 0,084 & 88,59 \\
& 90 & 0,080 & 0,080 & 0,079 & 0,080 & 89,13 \\
\hline 5,3 & DPPH & 0,877 & 0,877 & 0,877 & 0,877 & - \\
& 10 & 0,660 & 0,666 & 0,665 & 0,664 & 24,29 \\
& 30 & 0,117 & 0,216 & 0,219 & 0,184 & 79,02 \\
& 50 & 0,094 & 0,099 & 0,101 & 0,098 & 88,83 \\
& 70 & 0,044 & 0,037 & 0,052 & 0,044 & 94,98 \\
& 90 & 0,045 & 0,096 & 0,054 & 0,065 & 92,59 \\
\hline
\end{tabular}


Tabel 2. Nilai Serapan dan Peredaman Ekstrak Etanol daun Miana dengan Buffer Sitrat-Fosfat

\begin{tabular}{|c|c|c|c|c|c|c|}
\hline \multirow{2}{*}{ pH } & \multirow{2}{*}{$\begin{array}{c}\text { Konsentrasi } \\
\text { (ppm) }\end{array}$} & \multicolumn{4}{|c|}{ Absorbansi } & \multirow{2}{*}{$\begin{array}{c}\text { Peredaman } \\
(\%)\end{array}$} \\
\hline & & $\mathbf{1}$ & 2 & 3 & Rata-rata & \\
\hline \multirow{6}{*}{3} & DPPH & 0,812 & 0,812 & 0,812 & 0,812 & - \\
\hline & 10 & 0,631 & 0,708 & 0,664 & 0,667 & 17,86 \\
\hline & 30 & 0,525 & 0,505 & 0,489 & 0,506 & 37,69 \\
\hline & 50 & 0,295 & 0,290 & 0,311 & 0,298 & 63,30 \\
\hline & 70 & 0,164 & 0,139 & 0,164 & 0,115 & 80,91 \\
\hline & 90 & 0,091 & 0,120 & 0,085 & 0,098 & 87,93 \\
\hline \multirow{6}{*}{4} & DPPH & 0,736 & 0,736 & 0,736 & 0,736 & - \\
\hline & 10 & 0,595 & 0,601 & 0,609 & 0,602 & 18,21 \\
\hline & 30 & 0,321 & 0,320 & 0,319 & 0,320 & 56,52 \\
\hline & 50 & 0,116 & 0,110 & 0,112 & 0,113 & 84,65 \\
\hline & 70 & 0,082 & 0,086 & 0,084 & 0,084 & 88,59 \\
\hline & 90 & 0,080 & 0,080 & 0,079 & 0,080 & 89,13 \\
\hline \multirow{6}{*}{5,3} & DPPH & 0,901 & 0,901 & 0,901 & 0,901 & - \\
\hline & 10 & 0,843 & 0,845 & 0,847 & 0,845 & 6,22 \\
\hline & 30 & 0,587 & 0,588 & 0,589 & 0,588 & 34,74 \\
\hline & 50 & 0,413 & 0,379 & 0,378 & 0,390 & 56,71 \\
\hline & 70 & 0,211 & 0,212 & 0,213 & 0,212 & 76,47 \\
\hline & 90 & 0,156 & 0,161 & 0,161 & 0,159 & 82,35 \\
\hline \multirow{6}{*}{6} & DPPH & 0,683 & 0,683 & 0,683 & 0,683 & - \\
\hline & 10 & 0,450 & 0,449 & 0,449 & 0,499 & 26,94 \\
\hline & 30 & 0,372 & 0,369 & 0,374 & 0,372 & 45,53 \\
\hline & 50 & 0,218 & 0,227 & 0,230 & 0,225 & 67,06 \\
\hline & 70 & 0,231 & 0,230 & 0,238 & 0,233 & 65,89 \\
\hline & 90 & 0,230 & 0,243 & 0,244 & 0,239 & 65,01 \\
\hline \multirow{6}{*}{7} & DPPH & 0,868 & 0,868 & 0,868 & 0,868 & - \\
\hline & 10 & 0,750 & 0,771 & 0,771 & 0,764 & 11,98 \\
\hline & 30 & 0,425 & 0,419 & 0,398 & 0,414 & 52,30 \\
\hline & 50 & 0,322 & 0,319 & 0,309 & 0,316 & 63,59 \\
\hline & 70 & 0,303 & 0,325 & 0,329 & 0,319 & 63,25 \\
\hline & 90 & 0,337 & 0,336 & 0,337 & 0,336 & 61,29 \\
\hline \multirow{6}{*}{8} & DPPH & 0,577 & 0,577 & 0,577 & 0,577 & - \\
\hline & 10 & 0,456 & 0,464 & 0,471 & 0,464 & 19,65 \\
\hline & 30 & 0,525 & 0,534 & 0,524 & 0,528 & 8,56 \\
\hline & 50 & 0,562 & 0,562 & 0,562 & 0,562 & 2,59 \\
\hline & 70 & 0,624 & 0,625 & 0,624 & 0,624 & $-8,25$ \\
\hline & 90 & 0,697 & 0,689 & 0,695 & 0,694 & $-20,21$ \\
\hline
\end{tabular}




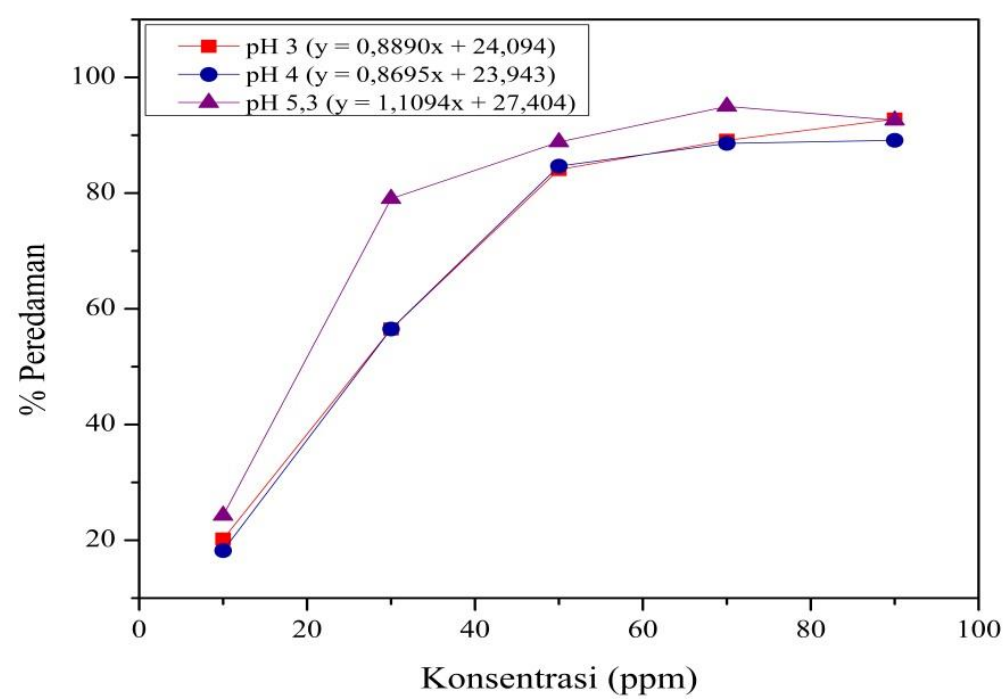

Gambar 1. Persamaan regresi linier dan hubungan konsentrasi ekstrak etanol daun miana terhadap persen peredaman dengan buffer Sitrat

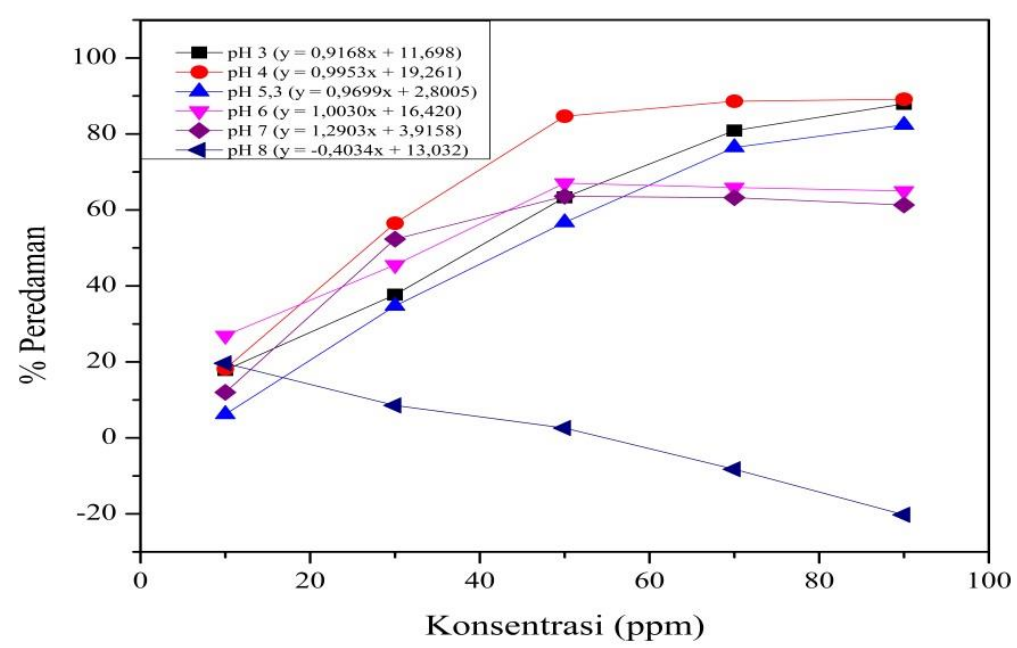

Gambar 2. Persamaan regresi linier dan hubungan konsentrasi ekstrak etanol daun miana terhadap persen peredaman dengan buffer Sitrat - Fosfat

Berdasarkan persamaan regresi yang telah diperoleh, maka nilai $\mathrm{IC}_{50}$ dapat dihitung dengan menentukan konsentrasi sampel uji yang menyebabkan persentase peredaman sebesar 50\% [13]. Nilai $\mathrm{IC}_{50}$ dari ekstrak etanol daun miana dengan buffer Sitrat dan buffer Sitrat - Fosfat disajikan dalam tabel 3. 
Tabel 3. Nilai $\mathrm{IC}_{50}$ Ekstrak daun Miana dengan Buffer Sitrat dan Buffer Sitrat-Fosfat

\begin{tabular}{lcccccc}
\hline \multirow{2}{*}{ Buffer } & $\mathbf{3}$ & $\mathbf{4}$ & $\mathbf{5 , 3}$ & $\mathbf{6}$ & $\mathbf{7}$ & $\mathbf{8}$ \\
\cline { 2 - 8 } Sitrat & $\begin{array}{c}29,14 \\
\mathrm{ppm}\end{array}$ & $\begin{array}{c}29,97 \\
\mathrm{ppm}\end{array}$ & $\begin{array}{c}20,37 \\
\mathrm{ppm}\end{array}$ & - & - & - \\
\hline \multirow{2}{*}{ Sitrat - Fosfat } & $\begin{array}{c}41,78 \\
\mathrm{ppm}\end{array}$ & $\begin{array}{c}30,88 \\
\mathrm{ppm}\end{array}$ & $\begin{array}{c}48,66 \\
\mathrm{ppm}\end{array}$ & $\begin{array}{c}34,48 \\
\mathrm{ppm}\end{array}$ & $\begin{array}{c}35,72 \\
\mathrm{ppm}\end{array}$ & $\begin{array}{c}-91,64 \\
\mathrm{ppm}\end{array}$ \\
\hline
\end{tabular}

Berdasarkan tabel 3 dapat diketahui bahwa perbedaan $\mathrm{pH}$ serta buffer mempengaruhi aktivitas antioksidan ekstrak etanol daun miana. Pengaruh perbedaan $\mathrm{pH}$ dan buffer dapat dilihat dari nilai $\mathrm{IC}_{50}$. Secara spesifik, suatu senyawa dikatakan sebagai antioksidan sangat kuat jika nilai $\mathrm{IC}_{50}$ kurang dari 50 $\mu \mathrm{g} / \mathrm{mL}$, kuat untuk $\mathrm{IC}_{50}$ bernilai $50-100 \mu \mathrm{g} / \mathrm{mL}$, sedang jika IC $\mathrm{I}_{50}$ bernilai 100-150 $\mu \mathrm{g} / \mathrm{mL}$, dan lemah jika IC 50 bernilai $151-200 \mu \mathrm{g} / \mathrm{mL}$ [13]. Jika dibandingkan tanpa menggunakan medium $\mathrm{pH}$ ( $\mathrm{IC}_{50} 48,04 \mathrm{ppm}$ ) pada buffer Sitrat $\mathrm{pH} 3$ dan 4 menunjukkan hasil nilai $\mathrm{IC}_{50}$ yang lebih baik, tetapi pada $\mathrm{pH}$ 5,3 terjadi penurunan persen peredaman pada konsentrasi $90 \mathrm{ppm}$. Hal ini menunjukkan bahwa pada $\mathrm{pH}$ 5,3 aktivitas antioksidan ekstrak etanol daun miana menjadi berkurang. Hal ini dikarenakan, senyawa metabolit sekundernya yang aktif sebagai antioksidan mulai tidak stabil.

Pada buffer Sitrat - Fosfat pH 3 dan 4 juga menunjukkan hasil nilai IC 50 yang lebih baik daripada tanpa menggunakan medium $\mathrm{pH}$. Pada $\mathrm{pH}$ 5,3 aktivitas antioksidan ekstrak etanol daun miana masih baik walaupun nilai $\mathrm{IC}_{50}$ tidak jauh berbeda dengan nilai $\mathrm{IC}_{50}$ tanpa menggunakan medium $\mathrm{pH}$. Seperti halnya pada pH 5,3 dengan buffer Sitrat, pH 6 dan 7 pada buffer Sitrat - Fosfat juga mengalami penurunan persen peredaman pada konsentrasi tinggi yaitu $70 \mathrm{ppm}$ dan 90 ppm. Sedangkan pada pH 8 aktivitas antioksidan menunjukkan hasil yang sangat tidak baik dimana semakin besar konsentrasi maka persen peredaman antioksidan semakin menurun. Hal ini disebabkan karena, senyawa metabolit sekundernya yang aktif sebagai antioksidan tidak stabil pada $\mathrm{pH}$ tinggi atau terjadi perubahan struktur dari senyawa aktif yang ada.

Daun miana memiliki antosianin yang merupakan salah satu kelompok senyawa flavonoid yang berperan memberikan warna ungu pada tanaman dan juga menghasilkan efek antioksidan. Senyawa antosianin yang terdapat pada daun miana adalah senyawa pelargonidin-3-rutinosida dan sianidin-3-O-glukosida [11]. Di dalam larutan, antosianin berada dalam lima bentuk kesetimbangan tergantung pada kondisi pH. Kelima bentuk tersebut yaitu kation flavilium, basa karbinol, kalkon, basa quinonoidal, dan quinonoidal anionik. Pada kondisi asam ( $\mathrm{pH}<2$ ) antosianin berada dalam bentuk ion oxonium atau garam flavilium yang cenderung lebih stabil.Pada nilai $\mathrm{pH}$ kisaran $2-4$ terbentuk spesies quinoidal 
berwarna biru.Bentuk tersebut dapat mengalami hidrolisis dengan meningkatnya $\mathrm{pH}$ membentuk pseudobasa yang mulai kehilangan warna yaitu bentuk basa karbinol pada $\mathrm{pH} 5$ dan bentuk kalkon pada $\mathrm{pH}$ 6. Pada $\mathrm{pH}$ di atas 7 akan membentuk basa quinonoidal berwarna biru [14]. Bentuk kesetimbangan antosianin dapat dilihat pada gambar 3 .

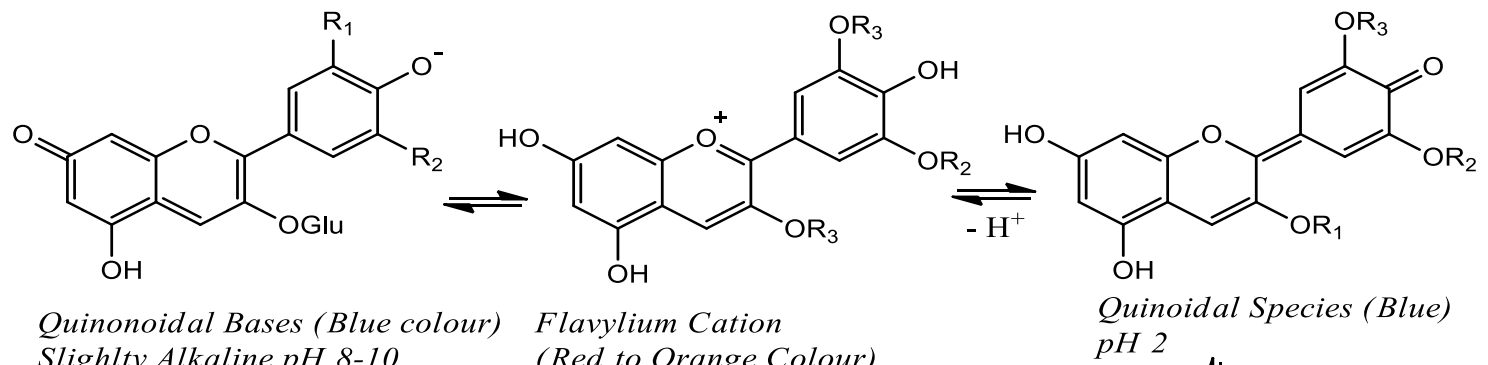

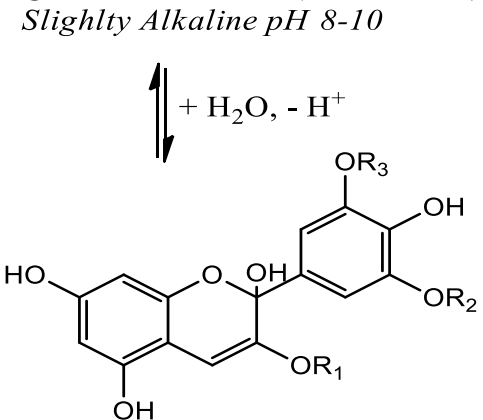
(Red to Orange Colour) pH 1

Carbinol Pseudobase (Colourless) pH 5<smiles>CCO/C(=C\c1c(O)cc(O)cc1O)C(=O)c1cc(OCC)c(O)c(OCC)c1</smiles><smiles>CCOc1cc2c(O)cc(=O)cc-2oc1-c1cc(OCC)c(O)c(OCC)c1</smiles>
Quinoidal Species (Blue) pH 3

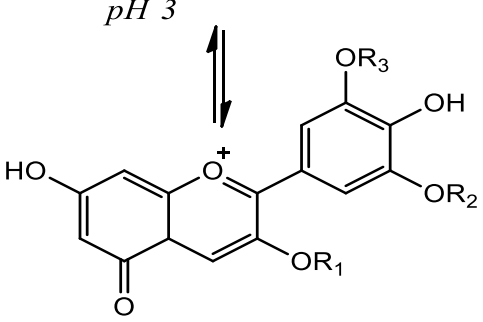

Quinoidal Species (Blue) pH 4

Chalcone (Colourless) pH 6

Gambar 3.Bentuk struktur dominan antosianinpada tingkat $\mathrm{pH}$ yang berbeda (R1 = $\mathrm{H}$ atau glikosida, $\mathrm{R} 2$ dan $\mathrm{R} 3=\mathrm{H}$ atau kelompok metil) [14]

Antosianin merupakan salah satu senyawa yang reaktif akibat kekurangan elektron dan hanya stabil pada kondisi asam [15]. Hasil penelitian (Laleh, 2006) menunjukkan bahwa peningkatan $\mathrm{pH}$ menyebabkan degradasi yang besar dari antosianin dalam sampel. Garam flavilium stabil hanya dalam kondisi yang sangat asam. Garam-garam ini kehilangan proton pada $\mathrm{pH}$ yang lebih tinggi dan berubah menjadi basis quinoidal, yang merupakan pigmen yang tidak stabil, dan segera berikatan dengan air dan membentuk senyawa tidak berwarna yang disebut 
chromenol [16]. Hal inilah yang menyebabkan pada buffer Sitrat dan buffer Sitrat-Fosfat pH 3 dan 4 menunjukkan aktivitas antioksidan yang lebih baik dibandingkan dengan $\mathrm{pH} 5,3 ; 6 ; 7$ dan 8 . $\mathrm{pH}$ yang paling baik untuk ekstrak etanol daun miana adalah $\mathrm{pH} 4$ dengan buffer Sitrat maupun dengan buffer Sitrat Fosfat.

\section{KESIMPULAN}

Berdasarkan hasil penelitian yang dilakukan dapat disimpulkan bahwa perbedaan $\mathrm{pH}$ dan buffer mempengaruhi aktivitas antioksidan. Aktivitas antioksidan ekstrak etanol daun miana menunjukkan nilai yang baik pada suasana asam. Nilai $\mathrm{IC}_{50}$ yang baik ialah pada $\mathrm{pH} 4$ dengan buffer Sitrat maupun dengan buffer Sitrat - Fosfat.

\section{DAFTAR PUSTAKA}

1. Wanti, Surtika. 2008. Pengaruh Berbagai Jenis Beras Terhadap Aktivitas Antioksidan pada Angkak oleh Monascus purpureus. Universitas Sebelas Maret: Surakarta.

2. Helliwel, B. and Gutteridge, J.M.C. 1999. Free Radicals in Biology and Medicine. Third Edition. Oxford University Press: New York.

3. Hernani dan Rahardjo, R. 2006. Tanaman Berkhasiat Antioksidan. Swadaya: Jakarta. 48-49.

4. Winarsi, H. 2007. Antioksidan Alami dan Radikal Bebas Potensi dan Aplikasi dalam Kesehatan. Kanisius: Yogyakarta.

5. Ahmad, Ahyar and Muh. Nasrum Massi. 2014. The Antituberculosis Rifampicin is Activated by 2',5'-Dimethyl Benzopelargonolactone from The Leaf Coleus atropurpureus L., Benth. International Journal of Pharma and Bio Science.5(1). (B) 758-764.

6. Sari, Devi. D. 2013. Uji Aktivitas Antioksidan Ekstrak Daun Miana(Coleus athropurpureus) Terhadap DPPH. Universitas Mulawarman: Samarinda.

7. Dalimartha, S. 2007. Atlas Tumbuhan Obat Indonesia Jilid I. Trubus Agriwidya: Jakarta.

8. Hendry, G. A. F. and Houghton, J. D. 1996. Natural Food Colorant Second Edition. Blackie Academic and Professional: London.

9. Hayati, E. K., Budi, U. S., dan Hermawan, R. 2012. Konsentrasi Total Senyawa Antosianin Ekstrak Kelopak Bunga Rosella (Hibiscus sabdariffa L.):Pengaruh Temperatur dan pH. Jurnal Kimia .6 (2). 138-147.

10. Setiono, Monica. H. 2013. Penentuan jenis Solven dan pH Optimum pada Analisis Senyawa Delphinidin dalam Kelopak Bunga Rosela dengan Metode Spektrofotometri Uv-Vis. Jurnal Teknik Kimia dan Industri. 2 (2). 91-96.

11. Hardiyanti, Yuniar., Djaswir Darwis dan Adlis Santoni. 2013. Ekstraksi dan Uji Antioksidan senyawa Antosianin dari Miana (Coleus scutellarioides L. (Benth)) Serta Aplikasi pada Minuman. Jurnal Kimia Unand. 2 (2). 44-50. 
12. Prakash, A., Rigelhof, F., Miller, E. 2001. Antioxidant Activity, dalam Rahayu. 2010. Penentuan Aktivitas Antioksidan dari Ekstrak Etanol Daun Ketapang (Terminalia catappa L) dengan Metode 1,1-Difenil-2-Pikrilhidrazil $(D P P H)$. UniversitasDiponegoro: Semarang.

13. Martiningsih, N. W., I Nyoman S., Putu E. Y. 2014. Skrining Fitokimia dan Uji Aktivitas Antioksidan dari Ekstrak Etanol Buah Terong Ungu (Solanum melongena L.). Jurnal Kimia. 8 (2). 145-152.

14. Miguel, M. G. 2011. Anthocyanins: Antioxidant and/or anti-inflammatory activities. Journal of Applied Pharmaceutical Science. 01 (06). 2.

15. Harborne, J. B. 1987. Metode Fitokimia : Penuntun Cara Modern Menganalisis Tumbuhan. Penerbit ITB: Bandung.

16. Laleh, G. H., H. Frydoonfar., and S. Zare. 2006. The Effect of Light, Temperature, $\mathrm{pH}$ and Spesies on Stability of Anthocyanin Pigments in Four Berberies Species. Pakistan Journal of Nutrition. 5 (1). 90-92. 